Volume 8. No. 10, October 2020

International Journal of Emerging Trends in Engineering Research

Available Online at http://www.warse.org/IJETER/static/pdf/file/ijeter578102020.pdf

https://doi.org/10.30534/ijeter/2020/578102020

\title{
An ion beam surface sputtering characteristics of magnesium substitutes in lead-based perovskite compound using SRIM-2013
}

\author{
Akinpelu A. ${ }^{1}$, Oyewande O. E. ${ }^{2}$ and Usikalu M. R. ${ }^{3}$ \\ ${ }^{1}$ Covennant University, Nigeria, akinwumi.akinpelu@cu.edu.ng \\ ${ }^{2}$ University of Ibadan, Nigeria. \\ ${ }^{3}$ Covennant University, Nigeria.
}

\begin{abstract}
The organic-inorganic lead halide perovskite are materials used for the production of low-cost and effective solar photovoltaic with a base made up of Electron Transport Layer (ETL) and the utmost effective of these organic-inorganic perovskite solar cells are made of Methylammonium Lead Iodide (MALI), $\mathrm{CH}_{3} \mathrm{NH}_{3} \mathrm{PbI}_{3}$ but the presence of lead has made it toxic. However, Magnesium metal cation could possibly replace lead in MALI since it is less-toxic We report another approach to study the behavior of perovskites without lead conducting a Monte Carlo (MC) sputtering calculation of of Methylammonium Lead Iodide (MAMI), lead and tin perovskites. The sputtering characteristics these materials were compared. The outcomes indicated a momentous display of comparable sputtering attributes with a greatest sputtering yield at $78^{\circ}$ ion incidences. The outcomes likewise demonstrated a relationship between the sputter values of MALI and MAMI.
\end{abstract}

Key words: IBSS, Sputter Yield, Magnesium Perovskite, Perovskite Solar Cell,

\section{INTRODUCTION}

The use of Perovskite solar cells (PSC) with an absorber material made of metal halide perovskites is associated to major encouraging PV devices for future of solar PVs. A notable increase in the conversion efficiency (PCE) from $3.8 \%$ [1-5] to over $22 \%$ within few years [6-8] confirmed this. This excellent piece is due to the special characteristics of metal halide perovskites displaying great high absorption coefficients, charge densities, direct tunable band gaps, hole transport and a balanced electron, [9], and long carrier diffusion lengths [10-12]. Other significant improvement is that they can be prepared via a variety of ways (13-21). A replacement of lead with non-toxic and naturally benign elements becoming lead-free perovskites can be obviously gotten by way of homovalent replacement of $\mathrm{Pb}$ with isovalent metallic cations like group-14 elements, transitions metals $(\mathrm{Mn}, \mathrm{Cu})$ and alkaline-earth metals $(\mathrm{Mg}, \mathrm{Ca})$. Quite a number of elements with constant oxidation state of ${ }^{+} 2$ are in more appropriate for replacement of $\mathrm{Pb}$ which has the same valence, in the perovskite structure. Group 2 metals in the periodic table as magnesium $(\mathrm{Mg})$ and barium $(\mathrm{Ba})$ can be possible alternatives because of suitable ionic radii, abundant, harmless and similar oxidation state to $\mathrm{Pb}^{2+}$ [22\&23]. On the other hand, alkaline earth metal perovskites exist stable perovskite structure [3, 23, and 24]. Magnessium has been reportedly used to substitute lead $(\mathrm{Pb})$ in methylammonium lead iodide perovskite structure leading to methylammonium magnesium iodide, but with lower effective masses, direct tunable band gaps and good absorption coefficients [25, 26]. The bandgaps of $\mathrm{AMgI} 3$ perovskites was projected to not to be fixed when different A-site cations are used with theoretical gaps of $1.5 \mathrm{eV}\left(\mathrm{CH}_{3} \mathrm{NH}_{3} \mathrm{MgI}_{3}\right), 0.9 \mathrm{eV}$ for $\left(\mathrm{CH}\left(\mathrm{NH}_{2}\right)_{2} \mathrm{MgI}_{3}\right)$ and $1.7 \mathrm{eV}\left(\mathrm{CsMgI}_{3}\right)$ [26]. Regardless of the smaller ionic radius of $\mathrm{Mg}^{2+}$ of $72 \mathrm{pm}$, magnesium halide perovskites was predicted theoretically to be stable [26, 27]. Amongst the alkaline-earth metals, $\mathrm{Mg}^{2+}$ has the best structural and optical data for photovoltaic applications, with more stability and a crystal system of tetragonal space group.

With the goal of reducing the toxicity of lead in perovskite applications, magnesium was used to replace lead in the pseudo-cubic phase $\mathrm{CH}_{3} \mathrm{NH}_{3} \mathrm{PbI}_{3}$ structure

To study the sputtering characteristics of materials, new method was proposed by Oyewande \& Akinpelu, 2018, by conducting ion beam surface sputtering using SRIM. Sputtering is the removal of atoms from particular target when bombarded by fast moving ion. There is ejection of atoms from the target material by energy transfer from an attacking particle, usually a gaseous ion. Benefit of sputtering is that materials with very high melting points are sputtered easily.

The MC suite built by Ziegler and Biersack[32-35]. It is therefore important to know the impact of lead substitution on 
Akinpelu A. et al., International Journal of Emerging Trends in Engineering Research, 8(10), October 2020, 6984 - 6988

the removal rates of hybrid organic and inorganic halide perovskites. By expansion, it is important to realize if sputter attributes, or modifications in them as certain component of perovskites is altered, has a correspondence with the conversion efficiencies of the perovskites.

In this paper, we used ion-beam machining method to examine the physical features responsible for differences in optoelectronic properties of both lead, lead-free metal halide perovskite materials and magnesium perovskite material in PV applications. And an MC simulation is employed study the sputtering characteristics of ions in lead and these selected lead free metal halide perovskite and perovskite of an alkaline-earth metal $\left(\mathrm{CH}_{3} \mathrm{NH}_{3} \mathrm{MgI}_{3}\right)$ for ion energies of $1 \mathrm{keV}$ and $5 \mathrm{keV}$ and different angles of incidence, using TRIM. Argon (Ar) and $\mathrm{Ne}$ (ion) ions were used to sputter these perovskite.

\section{METHODOLOGY}

The details of our simulation are given in this section and details on theoretical background for the calculation algorithm embedded in TRIM packages are explained in the publications written by Ziegler and Biersack [32-35]. The chosen range as prescribed in ref 29 was use as typical ion energy. TRIM was used to study the rate of removal of atoms of these selected perovskites when bombarded by fast moving argon and neon ions with $1 \mathrm{keV}$ and $5 \mathrm{keV}$ ion energies. The angle of incidence was varied from $0^{\circ}$ to $89^{\circ}$. In the set-up, 35 $\mathrm{nm}$ was the perovskite thickness used. The magnesium, lead and tin perovskites were built from as 1:3:1:3:1:3 for $\mathrm{C}, \mathrm{H}, \mathrm{N}$, $\mathrm{H}, \mathrm{Mg} / \mathrm{Pb} / \mathrm{Sn}$ and I, respectively. Density of $2.81 \mathrm{~g} / \mathrm{cm} 3$ was used for magnesium perovskite by using the correction factor suggested ref 29 while. Densities of $4.16 \mathrm{~g} / \mathrm{cm} 3$ [29] and 3.51 $\mathrm{g} / \mathrm{cm} 3$ [29] were used for the lead and tin perovskites, respectively. Exactly 1000 argon and neon ions were used, each, to hit the perovskite.

\subsection{Results and Discussion}

The outcome of our calculations are reported and explained here. Both results of the two incident ions $\left(\mathrm{Ne}^{+}\right.$and $\left.\mathrm{Ar}^{+}\right)$are presented. Although, higher values of $\mathrm{Ar}^{+}$sputter yield were found than the corresponding values for $\mathrm{Ne}^{+}$. The simulations were started with neon $\mathrm{Ne}^{+}$bombardments of the perovskites (Figures 1 - 6). The sputtering yields of magnesium halide perovskite show the same pattern as yields of lead and tin perovskites. Figures $8-11$ show the result of bombardment of argon $\mathrm{Ar}^{+}$ion with the selected perovskites. Similar pattern of sputter yield was noticed for magnesium perovskite, also. Although, among the three perovskites, magnesium halide perovskite has the lowest sputter yield. Methylammonium lead iodide has the highest yield while tin iodide perovskite recorded the second highest yield. The yields are inversely proportional to their recorded experimental power conversion efficiencies. Our results showed that magnesium can potentially replace lead in perovskite application.

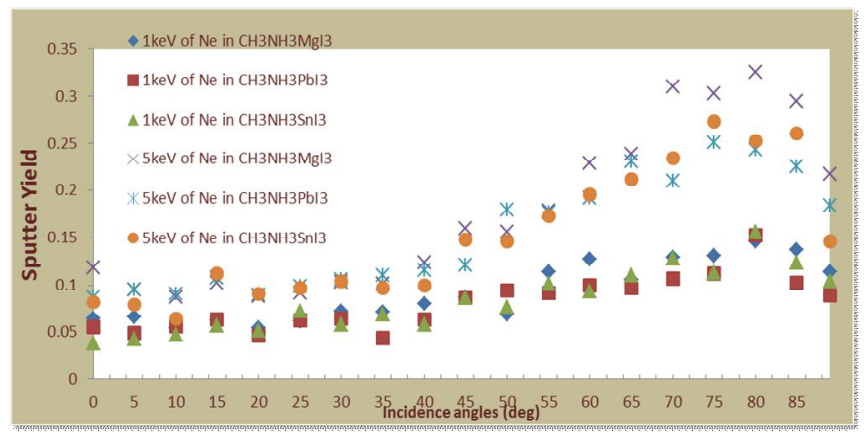

Figure 1: Sputter yield of Carbon for the erosion of $\mathrm{C}$ atoms from $\mathrm{Ne}^{+}$bombardment of target perovskites at different angles of incidence, for ion energy of $1 \mathrm{keV}$ and $5 \mathrm{keV}$

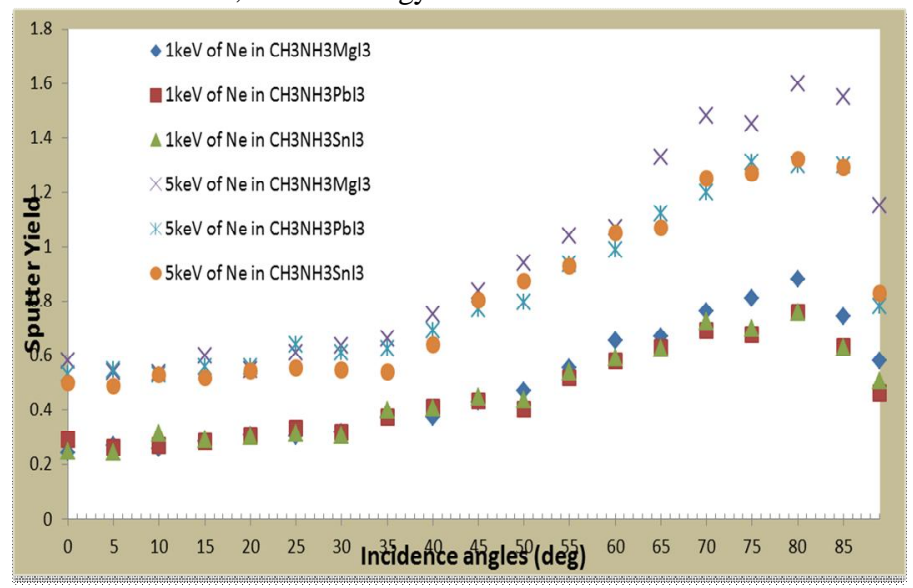

Figure 2: Sputter yield of Hydrogen for the erosion of $\mathrm{H}$ atoms from $\mathrm{Ne}^{+}$bombardment of target perovskites at different angles of incidence, for ion energy of $1 \mathrm{keV}$ and $5 \mathrm{keV}$.

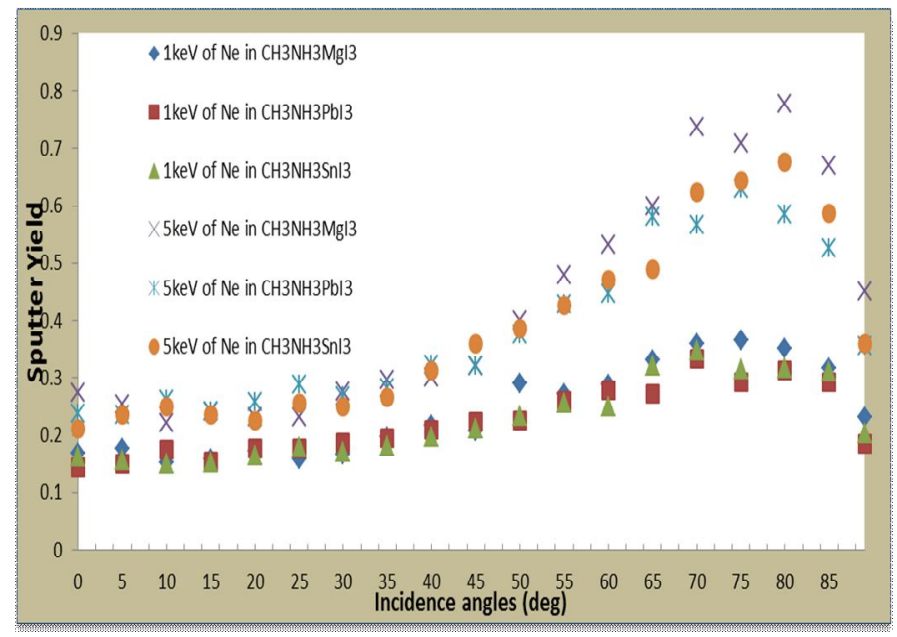

Figure 3: Sputter yield of Nitrogen for the erosion of $\mathrm{N}$ atoms from $\mathrm{Ne}^{+}$bombardment of target perovskites at different angles of incidence, for ion energy of $1 \mathrm{keV}$ and $5 \mathrm{keV}$ 
Akinpelu A. et al., International Journal of Emerging Trends in Engineering Research, 8(10), October 2020, 6984 - 6988

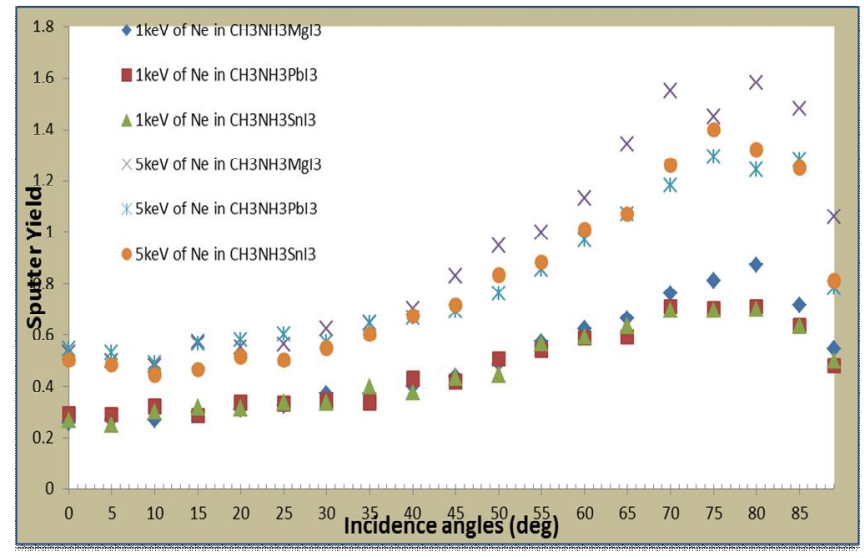

Figure 4: Sputter yield of Hydrogen for the erosion of $\mathrm{H}$ atoms from $\mathrm{Ne}^{+}$bombardment of target perovskites at different angles of incidence, for ion energy of $1 \mathrm{keV}$ and $5 \mathrm{keV}$

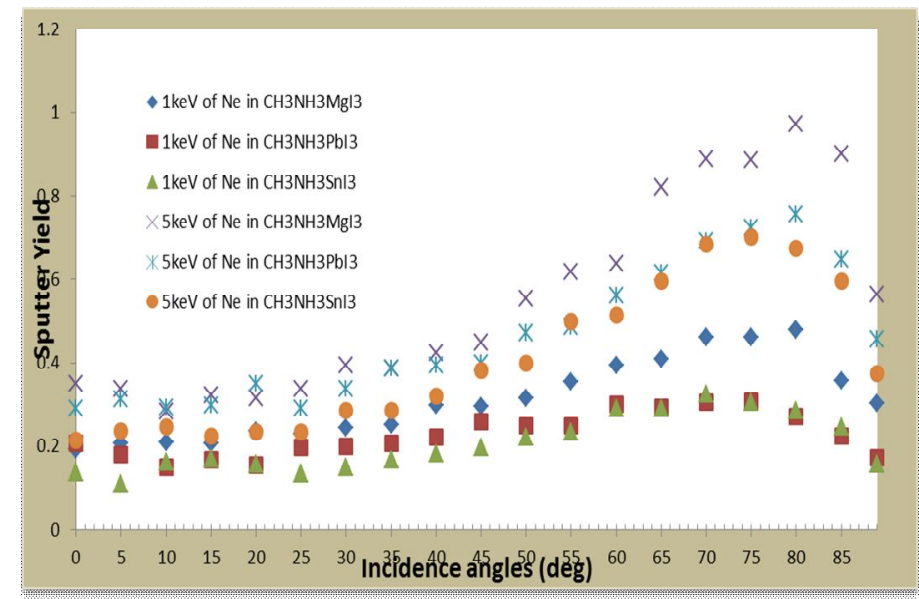

Figure 5: Sputter yield of $\mathrm{Mg} / \mathrm{Pb} / \mathrm{Sn}$ for their erosion from $\mathrm{Ne}^{+}$ bombardment of target perovskites at different angles of incidence, for ion energy of $1 \mathrm{keV}$ and $5 \mathrm{keV}$

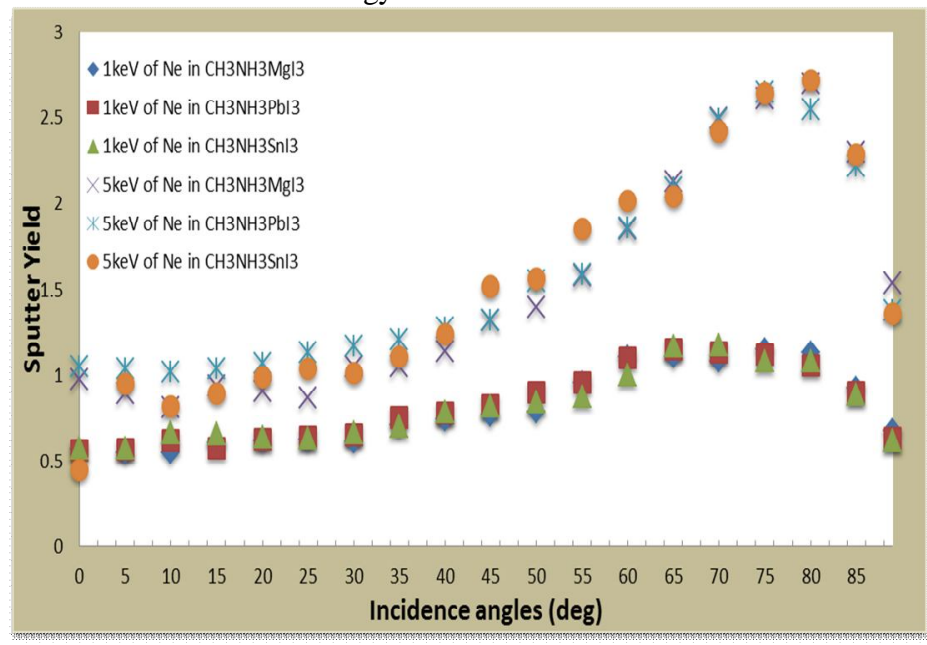

Figure 6: Sputter yield of Iodine for the erosion of I atoms from $\mathrm{Ne}^{+}$ bombardment of target perovskites at different angles of incidence, for ion energy of $1 \mathrm{keV}$ and $5 \mathrm{keV}$.
Results for Ar bombardment results are display below:

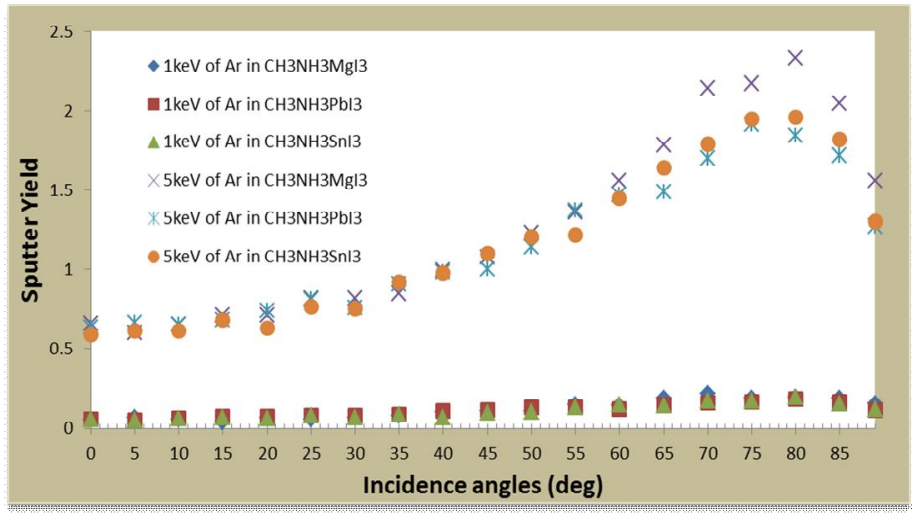

Figure 7: : Sputter yield of Carbon for the erosion of $\mathrm{C}$ atoms from $\mathrm{Ar}^{+}$bombardment of target perovskites at different angles of incidence, for ion energy of $1 \mathrm{keV}$ and $5 \mathrm{keV}$

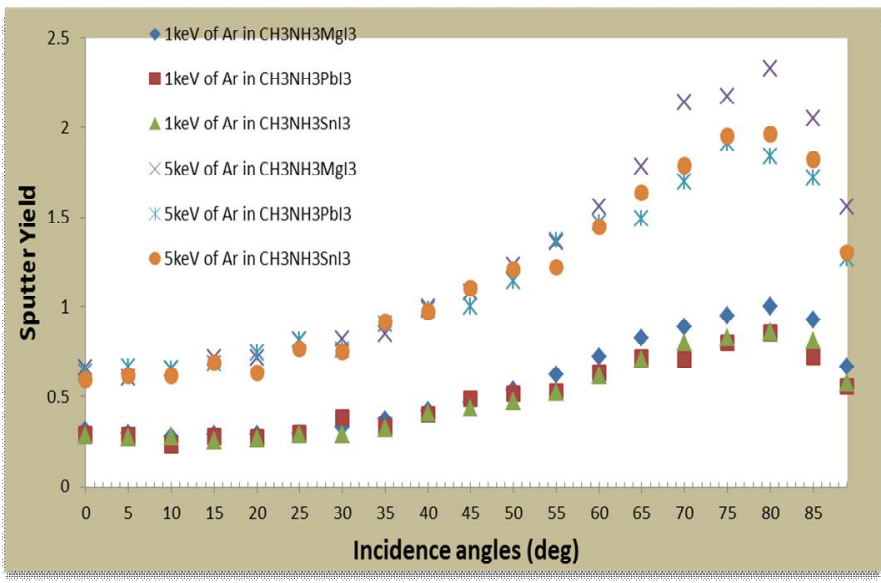

Figure 8: : Sputter yield of Hydrogen for the erosion of $\mathrm{H}$ atoms from $\mathrm{Ar}^{+}$bombardment of target perovskites at different angles of incidence, for ion energy of $1 \mathrm{keV}$ and $5 \mathrm{keV}$.

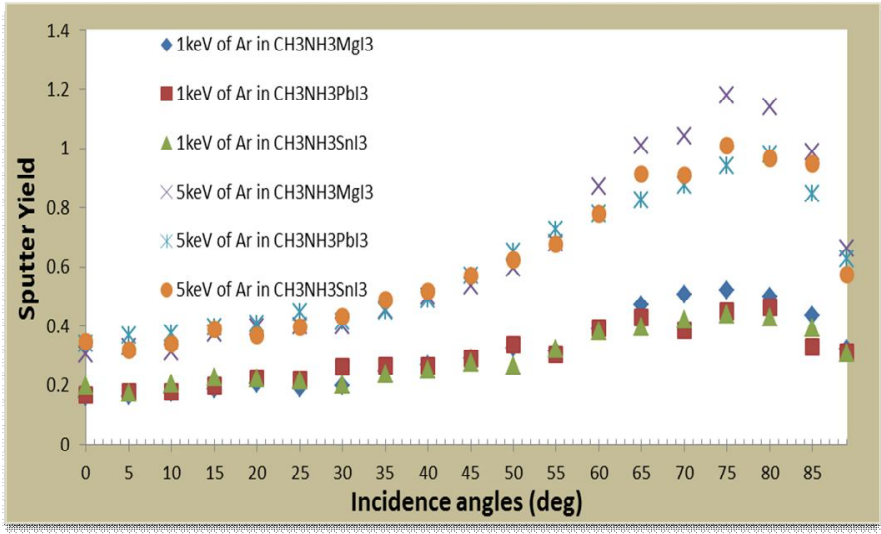

Figure 9: : Sputter yield of Nitrogen for the erosion of $\mathrm{N}$ atoms from $\mathrm{Ar}^{+}$bombardment of target perovskites at different angles of incidence, for ion energy of $1 \mathrm{keV}$ and $5 \mathrm{keV}$ 


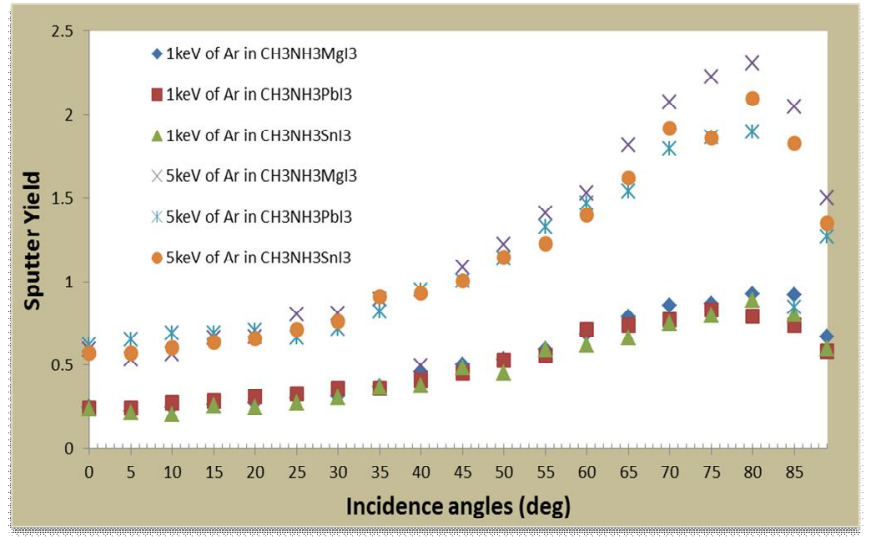

Figure 10: : Sputter yield of Hydrogen for the erosion of $\mathrm{H}$ atoms from $\mathrm{Ne}^{+}$bombardment of target perovskites at different angles of incidence, for ion energy of $1 \mathrm{keV}$ and $5 \mathrm{keV}$

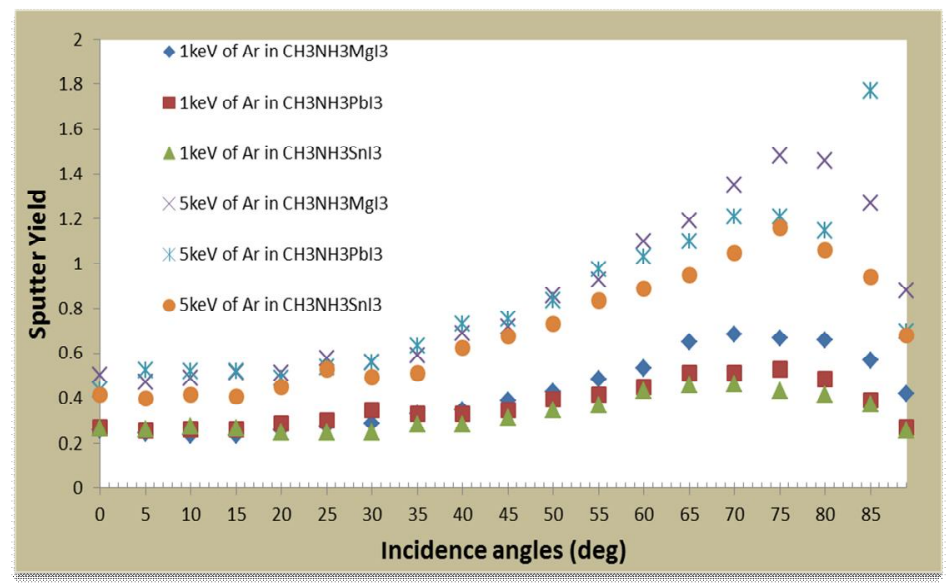

Figure 11: Sputter yield of $\mathrm{Mg} / \mathrm{Pb} / \mathrm{Sn}$ for their erosion from $\mathrm{Ar}^{+}$ bombardment of target perovskites at different angles of incidence, for ion energy of $1 \mathrm{keV}$ and $5 \mathrm{keV}$

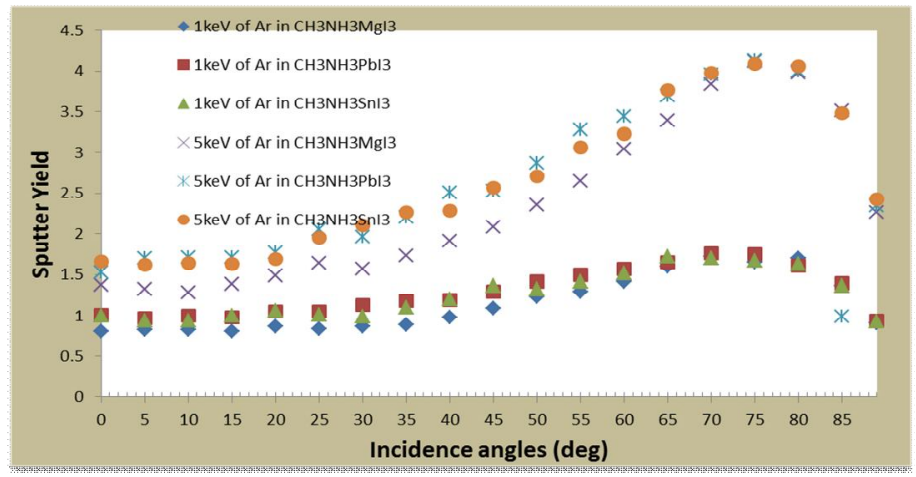

Figure 12: Sputter yield of Iodine for the erosion of I atoms from $\mathrm{Ar}^{+}$bombardment of target perovskites at different angles of incidence, for ion energy of $1 \mathrm{keV}$ and $5 \mathrm{keV}$.

\section{CONCLUSION}

An ion-beam surface sputtering IBSS approach has been done to examine the physical factors accountable for variations in optoelectronic properties of both lead and lead-free metal halide perovskite materials and magnesium perovskite material in PV applications. And an MC simulation was employed to study the sputtering characteristics of ions in lead and these selected lead free metal halide perovskite and perovskite of an alkaline-earth metal $\left(\mathrm{CH}_{3} \mathrm{NH}_{3} \mathrm{MgI}_{3}\right)$ as a new viewpoint of confirming if $\mathrm{Mg}^{+}$in methyl ammonium magnesium iodide has the same sputtering characteristics as $\mathrm{Pb}^{+}$so as to know if it's a possible substitute for lead.

In this research, it can be concluded that sputtering results of lead perovskite and its best substitute so far, tin perovskite are very similar to magnesium perovskite. Couple with other benefits reported by other researchers, our work further confirms that magnesium can replace lead in lead perovskite, if its power conversion efficiency is not too low.

\section{ACKNOWLEDGEMENT}

The authors will like to appreciate Covenant University for the support given

\section{REFERENCES}

1. S. Chan, M. Wu, K. Lee, W. Chen, T. Lin and W. Su, J. Mater. Chem. A, 2017, DOI: 10.1039/C7TA05720B.

2. M. Saliba, T. Matsui, K. Domanski, J.-Y. Seo, A. Ummadisingu, S. M. Zakeeruddin, J.-P. Correa-Baena, W. R. Tress, A. Abate, A. Hagfeldt and M. Gratzel, Science, 2016, 354, 206-209.

3. M. Saliba, T. Matsui, J.-Y. Seo, K. Domanski, J.-P. Correa-Baena, M. K. Nazeeruddin, S. M. Zakeeruddin, W. Tress, A. Abate, A. Hagfeldt and M. Gratzel, Energy Environ. Sci., 2016, 9,1989-1997.

4. N. J. Jeon, J. H. Noh, W. S. Yang, Y. C. Kim, S. Ryu, J. Seo and S. I. Seok, Nature, 2015, 517,476-480.

5. H.-C. Liao, P. Guo, C.-P. Hsu, M. Lin, B. Wang, L. Zeng, W. Huang, C. M. M. Soe, W.-F. Su, M. J. Bedzyk, M. R. Wasielewski, A. Facchetti, R. P. H. Chang, M. G. Kanatzidis and T. J. Marks, Adv. Energy Mater., 2016, 1601660.

6. Green MA, Emery K, Hishikawa Y, Warta W, Dunlop ED, Levi DH, Ho-Baillie AWY (2017) Prog Photovolt Res Appl 25:3

7. National Renewable Energy Laboratory (NREL). http://www.nrel.gov/pv/assets/images/efficiency_chart.jpg. Accessed 12 Aug 2016

8. Yang WS, Noh JH, Jeon NJ, Kim YC, Ryu S, Seo J, Seok SI (2015) Science 348:1234

9. Noh JH, Im SH, Heo JH, Mandal TN, Seok SI (2013) Nano Lett 13:1764

10. Stranks SD, Eperon GE, Grancini G, Menelaou C, Alcocer MJP, Leijtens T, Herz LM, Petrozza A, Snaith HJ (2013) Science 342:341

11. Dong Q, Fang Y, Shao Y, Mulligan P, Qiu J, Cao L, Huang J (2015) Science 347:967

12. Shi D, Adinolfi V, Comin R, Yuan M, Alarousu E, Buin A, Chen Y, Hoogland S, Rothenberger A, Katsiev K, Losovyj Y, Zhang X, Dowben PA, Mohammed OF, Sargent EH, Bakr OM (2015) Science 347:51

13. Lee MM, Teuscher J, Miyasaka T, Murakami TN, Snaith HJ (2012) Science 338:643

14. Burschka J, Pellet N, Moon S-J, Humphry-Baker R, Gao P, Nazeeruddin MK, Gra“tzel M (2013) Nature 499:316 
Akinpelu A. et al., International Journal of Emerging Trends in Engineering Research, 8(10), October 2020, 6984 - 6988

15. Wei Z, Chen H, Yan K, Yang S (2014) Angew Chem Int Ed 53:13239/

16. Sutherland BR, Hoogland S, Adachi MM, Kanjanaboos $\mathrm{P}$, Wong CTO, McDowell JJ, Xu J, Voznyy O, Ning Z, Houtepen AJ, Sargent EH (2015) Adv Mater 27:53

17. Akinpelu, A., Oyewande, O. E., Onumejor, C. A., Arijaje, T. E., Olawole, C., Ogunrionola, I., and Ogundile, O. P. (2019). Analytical form of sputtering in relation to surface binding energy for different types of perovskites. J. Phys.: Conf. Ser. 1299

18. Malinkiewicz O, Yella A, Lee YH, Espallargas GM, Graetzel M, Nazeeruddin MK, Bolink HJ (2014) Nat Photonics 8:128

19. Sebastian F. Hoefler, Gregor Trimmel, Thomas Rath. Progress on lead-free metal halide perovskites for photovoltaic applications: a review. Monatsh Chem (2017) 148:795-826 DOI 10.1007/s00706-017-1933-9

20. Uribe JI, Ramirez D, Osorio-Guille'n JM, Osorio J, Jaramillo F (2016) J Phys Chem C 120:16393

21. Pazoki M, Jacobsson TJ, Hagfeldt A, Boschloo G, Edvinsson T (2016) Phys Rev B Condens Matter Mater Phys 93:144105

22. Babayigit A, Duy Thanh D, Ethirajan A, Manca J, Muller M, Boyen H-G, Conings B (2016) Sci Rep 6:18721

23. Binek A, Petrus ML, Huber N, Bristow H, Hu Y, Bein T, Docampo P (2016) ACS Appl Mater Interfaces 8:12881

24. Choudhary K (2015) arxiv: 1505.01238

25. Filip MR, Giustino F (2016) J Phys Chem C 120:166

26. Johnson, O. O., Olutuase, P. E. and Oyewande, O. E. (2019). First principles calculations of the optoelectronic properties of magnesium substitutes in lead based ABX3 compounds. J. Phys.: Conf. Ser. 1299012129

27. Suta M, Wickleder C (2015) J Mater Chem C 3:5233

28. Oyewande $\mathrm{OE}$ and Akinpelu A, An ion-beam surface sputtering approach to the quest for lead-free metal halide perovskite for solar cells, Nucl. Instruments Methods Phys. Res. Sect. B Beam Interact. with Mater. Atoms, vol. 434, no. June, pp. 102-108(2018).

29. José Maria Clemente da Silva Filho, Viktor A. Ermakov, Francisco Chagas Marques, Perovskite thin film synthesised from sputtered lead sulphide, Sci. Rep. 8 (2018) 1563.

30. Raifuku, Y. Ishikawa, T. Bourgeteau, Y. Bonnassieux, P. Cabarrocas, Y. Uraoka, Fabrication of perovskite solar cells using sputter-processed CH3NH3PbI3 films, Appl. Phys. Expr. 10 (2017) 094101.

31. J. Ziegler, J. Biersack, “TRIM,” SRIM.

32. J. Ziegler, M. Ziegler, J. Biersack, The stopping and range of ions in matter, Nucl. Instrum. Meth. Phys. Res. B 268 (2010) 1818-1823.

33. S. Martinie, T. Saad-Saoud, S. Moindjie, D. Munteanu, J. Autran, Behavioral modeling of SRIM tables for numerical simulation, Nucl. Instrum. Meth. Phys. Res. B 322 (2014) 2-6.

34. W. Wilson, L. Haggmark, J. Biersack, Calculations of nuclear stopping, ranges, and straggling in the low-energy region, Phys. Rev. B 15 (1997) 2458. 